\title{
CREATING AND APPROPRIATING VALUE IN COOPERATION NETWORKS
}

\author{
Rita de Cássia Arantes ${ }^{1}$ Andréa Aparecida da Costa Mineiro ${ }^{2}$ (D) Cleber Carvalho de Castro ${ }^{3}$ (iD $_{\text {Leonardo Pinheiro Deboçã }}^{4}$
}

\author{
${ }^{I}$ Doutoranda em Administração. Universidade Federal de Lavras - UFLA. Lavras, Minas Gerais - Brasil. \\ ritadecassia.arantes@gmail.com \\ ${ }^{2}$ Doutora em Administração. Professora adjunta (UNIFEI). Universidade Federal de Itajubá -UNIFEI. Itajubá, Minas Gerais \\ - Brasil.andreamineiro@unifei.edu.br \\ ${ }^{3}$ Doutor em Agronegócios. Professor associado (UFLA). Universidade Federal de Lavras- UFLA. Lavras, Minas Gerais - \\ Brasil.clebercastro@ufla.br \\ ${ }^{4}$ Doutor em Administração. Professor associado (UFV-Campus Rio Paranaíba). Universidade Federal de Viçosa- UFV- \\ CRP. Rio Paranaíba, Minas Gerais - Brasil.leonardo.deboca@ufv.br
}

\section{Abstract}

Objective of the study: The objective of this research was to analyze how the processes of creation and appropriation of value are manifested in a horizontal agribusiness network

Methodology / approach: A case study was carried out in the Cerrado Mineiro Region (CMR) in which documentary research and interviews were used as source, whose data were analyzed through content analysis by frequency.

Originality / Relevance: There is little evidence in the literature about studies that explore processes of joint value creation and appropriation in horizontal networks. In view of this gap, the study proceeds by individually addressing the processes of creation and appropriation of value considering the nature of cooperation of the networks.

Main results: In relation to the results achieved, CMR creates value in cost reduction, differentiation by product, market expansion, expertise in the production of coffee, differentiation, dissemination and strengthening of the brand. Regarding the appropriation of value, CMR appropriates itself for the commercialization of potential quality coffee, the learning process, the premium paid in the cooperative's coffee, the valorization of the producer and for having a unique way for the production of coffee.

Theoretical / methodological contributions: Among the main contributions of this study, the individual analysis highlights the processes of creation and appropriation of value applied to horizontal networks. The considerations reinforce the fine line between the processes of creation and appropriation of relational value. That is, in addition to developing internal competencies and essential skills for the creation and appropriation of value, organizations must devise strategies to achieve a balance between these processes.

Keywords: Relational View. Capture of Value. Horizontal networks Agribusiness.

\section{CRIAÇÃO E APROPRIAÇÃO DE VALOR EM REDES DE COOPERAÇÃO}

\section{Resumo}

Objetivo do estudo: Objetivou-se, nesta pesquisa, analisar como os processos de criação e apropriação de valor se manifestam em uma rede horizontal do agronegócio.

Metodologia/abordagem: Foi realizado um estudo de caso, na Região do Cerrado Mineiro (RCM). Utilizou-se como fonte a pesquisa documental e entrevistas, cujos dados foram analisados, por meio de análise de conteúdo por frequência.

Originalidade/Relevância: Existem poucas evidências na literatura sobre estudos que explorem processos de criação e apropriação de valor conjunto em redes horizontais. Diante dessa lacuna, o estudo avança ao abordar, de maneira individualizada, os processos criação e apropriação de valor, considerando a natureza de cooperação das redes.

Principais resultados: Em relação aos resultados alcançados, a RCM cria valor na redução de custos, diferenciação por produto, ampliação de mercado, expertise na produção de cafés, diferenciação, disseminação e fortalecimento da marca. Já, em relação à apropriação de valor, a RCM se apropria pela comercialização do café de potencial qualidade, processo de aprendizagem, prêmio pago no café do cooperado, valorização do produtor e por ter uma maneira singular para a produção de cafés.

Contribuições teóricas/ metodológicas: Entre as principais contribuições, deste estudo, destaca-se a análise individual dos processos de criação e apropriação de valor aplicado às redes horizontais. As considerações reforçam a linha tênue entre os processos de criação e apropriação de valor relacional. Ou seja, além de desenvolver competências internas e habilidades essenciais para a criação e apropriação de valor, as organizações devem traçar estratégias para atingir o equilíbrio entre esses processos.

Palavras-chave: Visão Relacional. Captura de Valor. Redes Horizontais. Agronegócio

\section{CREACIÓN DE VALOR Y APROPIACIÓN EN REDES DE COOPERACIÓN}

\begin{abstract}
Resumen
Objetivo del estudio: El objetivo de esta investigación fue analizar cómo los procesos de creación y apropiación de valor se manifiestan en una red horizontal de agronegocios.

Metodología / abordaje: Se realizó un estudio de caso en la Región Cerrado Mineiro (RCM). Se utilizó como fuente la investigación documental y las entrevistas, cuyos datos fueron analizados mediante análisis de contenido por frecuencia.

Originalidad / Relevancia: Existe poca evidencia en la literatura sobre estudios que exploren procesos de creación y apropiación conjunta de valor en redes horizontales. Ante esta brecha, el estudio avanza abordando individualmente los procesos de creación y apropiación de valor considerando la naturaleza de la cooperación de las redes.

Principales resultados: En relación a los resultados alcanzados, RCM genera valor en reducción de costos, diferenciación por producto, expansión de mercado, especialización en la producción de café, diferenciación, difusión y fortalecimiento de la marca. En cuanto a la apropiación de valor, RCM se apropia para la comercialización de café de calidad potencial, el proceso de aprendizaje, el premio pagado en el café de la cooperativa, la valorización del productor y por tener una forma única para la producción de café

Aportes teórico-metodológicos: Entre los principales aportes de este estudio, el análisis individual destaca los procesos de creación y apropiación de valor aplicados a las redes horizontales. Las consideraciones refuerzan la delgada línea entre los procesos de creación y apropiación de valor relacional. Es decir, además de desarrollar competencias internas y habilidades esenciales para la creación y apropiación de valor, las organizaciones deben idear estrategias para lograr un equilibrio entre estos procesos.
\end{abstract}

Palabras clave: Visión relacional. Captura de valor. Redes horizontales. Agroindustria.

Cite as / Como citar

American Psychological Association (APA)

Arantes, R. de C., Mineiro, A. A. da C., Castro, C. C., \& Deboçã, L. P. (2021). Creating and appropriating value in cooperation networks. Iberoamerican Journal of Strategic Management (IJSM), 20, 1-23, e18242. https://doi.org/10.5585/riae.v20i1.18242.

ARANTES, Rita de Cássia; MINEIRO, Andréa Aparecida da Costa; CASTRO, Cleber Carvalho de; DEBOÇÃ, Leonardo Pinheiro. Creating and appropriating value in cooperation networks. Iberoamerican Journal of Strategic Management (IJSM), v. 20, p. 1-23. 2021. https://doi.org/10.5585/riae.v20i1.18242. 


\section{Introduction}

Market complexity has reshaped conceptions of business competitiveness (Reypens et al., 2016). Business strategies for competitive advantage are translated into competition or cooperation between companies and partners, and influenced by economic globalization (Lee et al., 2014; Martins et al., 2017; Zhang \& Wang, 2018).

The concept of competitive advantage is analyzed through different theoretical lenses (Miguel et al., 2014). For example, the concept of value, proposed by Bowman and Ambrosini (2000), members value with meeting consumer needs. For Corte and Gaudio (2014) however, the concept of value is interpreted from different targets for whom value can be created. However, there seems to be a movement converging on the concept of competitive advantage for superior value creation (Martins et al., 2017). Therefore, a company's competitive advantage should not be considered synonymous with superior performance (Peteraf \& Barney, 2003). In other words, a company, even if it has some competitive advantage, only outperforms another if it can appropriate the value created (Coff, 1999, 2010)

The concepts of value creation and appropriation can be considered as ways of launching new discussions about company performance. While value creation can be understood as the process of "accumulation and transformation of valuable resources which increase the perceived use value of a company's products" (Pavlínek \& Ženka, 2016, p. 941), value appropriation can be understood as "the company's ability to capture material (income) or intangible (e.g., knowledge, reputation) value received in exchange for use value created for potential users (Dubosson-Torbay, et al., 2002, p. 182)".

Although the concept of value creation has been featured in the literature as a means to explain a company's competitiveness, in recent decades there is evidence that the ability to appropriate value seems to be as important as the ability to create it (Wang \& Rajagopalan, 2015). In this regard, the works of Wang and Rajagopalan (2015) and Fischer and Sojer (2015) show that there are few efforts in the literature to jointly understand the processes of creation and appropriation of value. For the authors, a large part of the work is committed to exploring how value is created (Bowman \& Ambrosini, 2000; Lepak et al., 2007; Coff, 2010; Corte \& Gaudio, 2014). Accordingly, Makadok and Coff (2002) and Corte e Gaudio (2014) point out the importance of an individual look at the processes of creation and appropriation of value, since they may require different skills and abilities from companies. It is worth mentioning that there is an emphasis in the literature on investigating the processes of creation and appropriation of value in vertical networks (Fischer \& Sojer, 2015; Reypens et al., 2016; Gandia \& Parmentier, 2017; Dyer et al., 2018). In summary, these studies discussed how the different network links (suppliers, buyers, companies, and others) appropriate the created value. However, there is little evidence in the literature about studies that explore these processes in horizontal networks, those companies that choose to coordinate some of their activities together, but these companies are independent from each other (Balestrin \& Verschoore, 2016). 
Although it is recognized that there is a need for studies that individually consider the processes of creation and appropriation of value in horizontal networks, no studies were found to overcome this gap. The importance of investigating the issue lies in the fact that companies may need distinct resources and strategies to either create value or appropriate the value. This is important in cooperation networks, considering that the concept of synergy and complementarity of resources are critical factors for the longevity of these structures (Pereira \& Pedroso, 2005). In other terms, opening the black box of value creation and appropriation can allow companies to look at their own capacities and strategies, as well as their performance in the network. Moreover, for cooperation networks, this seems even more significant since the value created by the network must be distributed among its parts. In view of this, the study is guided by the following research question: How do the processes of creation and appropriation of value manifest themselves in a horizontal agribusiness network? Therefore, the objective of this article is to analyze how the processes of creation and appropriation of value manifest themselves in a horizontal agribusiness network.

To answer this question, the Cerrado Mineiro Region was chosen as the empirical field of this study. The Cerrado Mineiro Region (CMR) encompasses 55 cities located in the mesoregions of the Triângulo Mineiro, Alto Paranaíba and Northwest of Minas, which have uniform weather patterns, thus providing for the production of recognized specialty coffees. CMR is currently composed of seven cooperatives, seven associations and a foundation that act as members in the implementation of the strategic plans elaborated together with a foundation. According to data from Federation of Coffee Growers of the Cerrado (FCC) and the National Supply Company (CONAb), the region covers 4,500 producers in a production area of 234,000 hectares. Coffee production in the Cerrado Mineiro Region represents $12.7 \%$ of all Brazilian coffee production and $25.4 \%$ of the total production of Minas Gerais (Cerrado Mineiro Region, 2020). The intensity of activity in this region is representative to the Brazilian economy since it has produced 6 million bags in 2020, an increase of $30.7 \%$ compared to the previous period (Conab, 2020).

The paper is structured in four sections as well as this introduction. The next section presents the main theoretical aspects underlying the research, such as value creation and appropriation. Next is the methodological course, based on a case study of the Cerrado Mineiro Region. Section four presents the results, organized according to specific objectives. Finally, section five gives the conclusions, limitations, and proposals for future studies.

\section{Theoretical framework}

\section{Competitive advantages in the relational perspective}

Dyer and Singh (1998), faced with the potential of relationships for organizational competitive advantage, resume the conception of collective strategies of action and introduce a new approach: the "relational view" of competitive advantage. Collective strategies are actions of cooperation between 
organizations, which arise from the needs of leading organizations such as market instability. From the perspective of the relational view, the competitiveness of the organization is not limited to its internal resources, but also constitutes of resources that the organization accesses through relationships (Dyer \& Sing, 1998; Lavie, 2007).

Specifically regarding cooperation networks, Balestrin and Verschoore (2016) present some advantages derived from network relationships, which can act in the strengthening of the company's competitiveness, namely: i) scale of power and market; ii) generation of collective solutions; iii) reduction of costs and risks; iv) collective learning and; v) collaborative innovation. Table 1 summarizes the main advantages, as well as their benefits to the members.

Table 1 - Competitive advantages derived from network relationships

\begin{tabular}{|c|c|c|}
\hline $\begin{array}{l}\text { Competitive } \\
\text { advantages }\end{array}$ & Definition & Benefits to the members \\
\hline $\begin{array}{c}\text { Scale of Power and } \\
\text { Market }\end{array}$ & $\begin{array}{l}\text { Possibility of expanding the capacity of } \\
\text { action of a company through union with } \\
\text { other companies and institutions. }\end{array}$ & $\begin{array}{l}\text { Bargaining power, } \\
\text { representativeness, } \\
\text { market strength. }\end{array}$ \\
\hline $\begin{array}{l}\text { Generation of } \\
\text { collective solutions }\end{array}$ & $\begin{array}{l}\text { It concerns all services, products and } \\
\text { infrastructure available for the joint } \\
\text { development of its members. }\end{array}$ & $\begin{array}{l}\text { Training, business consulting, credit } \\
\text { guarantee, marketing structures. }\end{array}$ \\
\hline $\begin{array}{l}\text { Reduction of costs } \\
\text { and risks }\end{array}$ & $\begin{array}{l}\text { It refers to the sharing of costs and risks } \\
\text { of certain actions that are common to the } \\
\text { members. }\end{array}$ & $\begin{array}{l}\text { Shared activities, complementarity of } \\
\text { resources, transactional facility. }\end{array}$ \\
\hline Collective learning & $\begin{array}{l}\text { The socialization of knowledge among } \\
\text { the members and the access to external } \\
\text { knowledge. }\end{array}$ & $\begin{array}{l}\text { Access to new external knowledge, } \\
\text { internal and external benchmarking. }\end{array}$ \\
\hline $\begin{array}{l}\text { Collaborative } \\
\text { innovation }\end{array}$ & $\begin{array}{l}\text { Innovative actions developed jointly by a } \\
\text { company. }\end{array}$ & $\begin{array}{l}\text { New products, adoption of new } \\
\text { organizational practices, access to } \\
\text { new markets and business } \\
\text { development. }\end{array}$ \\
\hline
\end{tabular}

Source: Adapted from Balestrin and Verschoore (2016).

Given the numerous competitive advantages that cooperation networks are able to offer their members, Balestrin and Verschoore (2016) state that many of them also contribute to the value creation process, since collective solutions have the potential to provide rare advantages that are difficult to imitate, such as reputation or network image. Ngugi et al. (2010) state that companies can create value through their relationships. For the authors, the relationship between network actors is a dynamic process that allows the sharing of risks, the establishment of new skills, in addition to providing advantages in cost or revenue. When dealing with relationships, specifically in cooperation networks, elements such as trust, commitment and communication between companies are also highlighted by Corte and Gaudio (2014) and Claro et al. (2003) as important factors for creating value in networks. This topic will be addressed as follows. 


\section{Value creation according to the Relational View}

The origins and definitions of the concept of value creation are composed of different types of actors and interpreted based on the different targets for which value can be created (Corte \& Gaudio, 2014). Thus, it becomes possible to understand value creation as: the result of human work (Marx, 1990), entrepreneurial effort (Bowman \& Ambrosini, 2000), knowledge (Coff, 2010), resources (Barney, 1991; Barney \& Hesterly, 2006) or distinctive company activities (Porter, 1985). In addition, there are many other factors which affect value creation, such as: virtual markets, value chains, innovation, human and company resources, strategic networks and others (Ito et al., 2012).

In the organizational view, "value is created when companies develop or innovate in ways of doing things, whether through new methods, technology or new forms of raw material" (Lepak et al., 2007, p. 182). For Bowman and Ambrosini (2000), those responsible for assigning a "new use value" to the inputs of the organization are its own members. Therefore, value is created through interactions between members, routines, processes and tools in an organization (Corte \& Gaudio, 2014).

From this perspective, the concept of value creation should not be limited to profit, but should be analyzed from a broader perspective. In addition to profit, value creation can be translated into collaboration, knowledge spillovers, reputation (brand and image), and transaction cost savings of the organization (Corte \& Gaudio, 2014; Pavlínek \& Ženka, 2016).

Thus, in an attempt to explore the possibilities of value creation between companies, specifically in interorganizational relations, Dyer and Singh (1998) add the "relational view" approach of competitive advantage. The authors suggest four potential sources of competitive advantage, namely: relationship-specific assets; sharing knowledge and routines; complementary resources and skills; and effective governance. Table 2 summarizes these sources of competitive advantage.

Table 2 - Sources of competitive advantage from a relational perspective

\begin{tabular}{l|l}
\multicolumn{1}{c}{$\begin{array}{c}\text { Sources of } \\
\text { Competitive } \\
\text { Advantage }\end{array}$} & \multicolumn{1}{c}{ Definitions } \\
\hline $\begin{array}{l}\text { Relationship specific } \\
\text { assets }\end{array}$ & $\begin{array}{l}\text { These are idiosyncratic assets from alliances between companies under effective } \\
\text { governance mechanisms. Synergy in the combination of resources can reduce } \\
\text { transaction costs or provide relationship gains. }\end{array}$ \\
\hline $\begin{array}{l}\text { Knowledge sharing } \\
\text { routine }\end{array}$ & Exchanges of information and knowledge in interorganizational relationships. \\
\hline $\begin{array}{l}\text { Complementary } \\
\text { resource/ Capacities }\end{array}$ & $\begin{array}{l}\text { Complementation between companies, either through outsourcing or other } \\
\text { mechanisms. }\end{array}$ \\
\hline Governance & $\begin{array}{l}\text { These are coordination mechanisms which can reduce transaction costs and leverage } \\
\text { relational gains through synergy in the combination of assets, skills and knowledge. }\end{array}$
\end{tabular}

Source: Prepared based on Dyer and Singh (1998).

It is important to point out that relational gains happen when network partners are able to create, share and invest in idiosyncratic assets, knowledge and resources, as well as governance use 
mechanisms which can reduce transaction costs and/or encourage gains through synergies in knowledge sharing and combining specific assets (Dyer \& Singh, 1998).

Balestrin et al. (2014) add that, over time, it becomes a challenge for companies to control and retain ownership of assets which have become valuable. Thus, the pursuit of value creation stems from companies' ability to coordinate and complement resources with partners, and not just by developing individual valuable resources. In this way, the company's competitive advantage is not limited to internal resources, but is also those resources accessed by it, which derive from their relationships (Dyer \& Singh, 1998; Lavie, 2006).

The relationship between the actors in the network is a dynamic process that allows risks to be shared and new skills to be established, as well as providing cost or revenue advantages (Ngugi et al., 2010). Moreover, relationships in cooperation networks involve elements such as trust, commitment, and communication between companies, as a factor for creating value in networks (Corte \& Gaudio, 2014)

Wang and Rajagopalan (2015) state that organizations can create value, specifically when the network is already consolidated, through learning and enhancing complementary assets while addressing conflicts, unexpected contingencies and moral risks. Therefore, organizations in cooperation networks are able to create value through a dynamic and interactive process of sharing and recoding individual and collective resources (Dyer \& Singh, 1998; Gulati, 1999).

\section{Value appropriation according to the relational view}

Despite the importance attached to the concept of value creation to explain a company's competitiveness, in recent decades, some scholars (Coff, 1999, 2010; Lavie, 2006; Zhao et al., 2014) have identified that value appropriation capacity seems to be as important as that of creation. As highlighted by Coff $(1999,2010)$, a company only outperforms another if it is able to capture the value created. While value creation can be conceptualized as an innovation or reconfiguration of assets and skills to create new use value (Gandia \& Parmentier, 2017), capturing or appropriating value refers to "the company's ability to capture material (income) or intangible (knowledge, reputation) value received in exchange for a use value created based on potential users (Dubosson-Torbay et al., 2002, p. 182).

With this, the competitive advantage of an organization can also be explained by the excellence of appropriation of the created value. Therefore, the organization must direct itself to translate the use value of its products. The more value an organization is able to appropriate, the greater its potential for obtaining competitive advantage (Fischer \& Sojer, 2015).

From a critical and dynamic view, Dyer et al. (2018) presented a review of the approach itself, the Relational View, in order to explain how the processes of value creation and appropriation unfolded over time. The authors consider the four forms of value creation (Table 2) and present four new ways 
for the value appropriation process, including: (i) replicating or replacing complementary resources; (ii) development of additional resources; (iii) asymmetric investment in specific assets; and (d) preventing imitation of its appeal. The summary is explained in Table 3.

Table 3 - Forms of value appropriation according to the relational view

\begin{tabular}{l|l}
\multicolumn{1}{c|}{$\begin{array}{c}\text { Sources of value } \\
\text { appropriation }\end{array}$} & \multicolumn{1}{c}{ Definitions } \\
\hline $\begin{array}{l}\text { Partner resource } \\
\text { replication }\end{array}$ & $\begin{array}{l}\text { An organization's ability to assimilate or replicate its partner's knowledge and } \\
\text { resources. This can change the balance of bargaining power and this organization } \\
\text { should be able to capture a larger percentage of the joint value created over time. }\end{array}$ \\
\hline $\begin{array}{l}\text { Development of } \\
\text { additional resources }\end{array}$ & $\begin{array}{l}\text { An organization's ability to build or acquire new resources that are valuable to the } \\
\text { relationship. }\end{array}$ \\
\hline $\begin{array}{l}\text { Asymmetrical } \\
\text { investment in specific } \\
\text { assets }\end{array}$ & $\begin{array}{l}\text { Will result over time in greater bargaining power (greater ability to appropriate } \\
\text { relational gains in ongoing negotiations). }\end{array}$ \\
\hline Preventing imitation & The company's ability to prevent competitors from creating a similar feature. \\
\hline
\end{tabular}

Source: Prepared by the authors based on Dyer et al. (2018).

Corte and Gaudio (2014) mention that the process of value appropriation may require various skills and instruments, according to the levels of the organization. Therefore, leadership can play a unique role in value appropriation in a company, as it acts as a bridge between organizational learning actors and the structures and routines influencing the learning process. It is noteworthy that in some contexts companies are able to appropriate more value than they create, whereas in others the opposite is true: some companies are able to appropriate only part of the value they have created (Fischer \& Sojer, 2015).

Despite the intertwined relationship between value creation and appropriation, Fischer and Sojer (2015) state that there are many gaps in the field. For the authors, it is clear that organizations need to at least create some kind of value in order to appropriate part of it. However, beyond this primary need, organizations need to devise different strategies whether they intend to create or appropriate value. Thus, there are organizations whose focus is on building barriers around appropriated value (Pitelis, 2009), while on the other hand there are organizations which compete primarily for value creation, for example by striving to innovate faster than the competitor (Mizik \& Jacobson, 2003).

\section{Methodological procedures}

This research has qualitative nature. Given the goals of the research, it can be classified as descriptive, since it aims to understand how the processes of creation and appropriation of value manifest themselves in a horizontal network of coffee agribusiness in the Cerrado Mineiro Region (CMR). To this end, the case study, characterized by Yin (2001) as a kind of critical and in-depth analysis of a research phenomenon, was used. 
CMR, the empirical field of this study, covers a set of coffee growers with particular characteristics for Geographical Indication (registration recognizing the reputation, qualities and characteristics linked to the location). There are currently seven cooperatives, seven associations and a foundation operating in developing activities to ensure compliance with legal requirements and quality assurance (Pereira \& Pedrozo, 2005; Moura, 2016). The CMR was initially developed by state incentives to stimulate coffee production in the region (Ortega \& Jesus, 2011). However, in the period of 1990, the region faced serious problems in a context of deregulation of the sector, which according to Mafra (2008) allowed the region to undergo organizational restructuring. As a way to react to the negative effects of the situation, the coffee growers of the Cerrado Mineiro mobilized for the creation of associations of producers from the municipalities of the coffee region, and the Council of Associations of Coffee Growers of the Cerrado (CACCER), currently the Federation of Coffee Growers of the Cerrado (FCC) (Ortega \& Jesus, 2011) emerged. Nagai (2016) and Moura (2016) state that the CMR's trajectory with the network stood out from the others. While the other regions were more conversational in coffee production, CMR, from the beginning, was more innovative, focused on the quality of the beans produced. Currently, CMR seeks to expand and consolidate its brand in foreign markets through the production of a coffee called "attitude" (Cerrado Mineiro Region, 2020). To this end, the Region has specific initiatives for each member interested in the network. The field becomes a unique case for research, due to the expertise of producers in the production and marketing of specialty coffees. In addition, the network has a promising history of creating value through collaboration. Furthermore, a cooperation network must not only create value but also distribute it among its parties. Therefore, CMR becomes a unique empirical field for the observation of the investigated phenomenon.

Primary and secondary sources were adopted for data collection. The primary sources consist of in-depth semi-structured interviews conducted in order to obtain more detailed information regarding the relationships and functioning of the network studied. Secondary sources, on the other hand, consist of documents, represented by information about the Cerrado Coffee Growers Federation (FCC) and its members, articles and corporate bulletins (general information about activities developed and future activities), as well as information available on their websites. The documents were used in the analysis of content as a way to reinforce or counteract the evidence gathered. Thus, the study corpus comprised 11 interviews, five with associations, five with cooperatives and one with the FCC, in addition to the documents mentioned above. The interviews take place between September and November 2018. To ensure the preservation of the identities of the entities and interviewees, they were coded as AA, AB, AC, AD, AE, C1, C2, C3, C4, C5 and FCC. In-depth interviews were conducted using a semi-structured script applied to individuals in strategic positions (supervision and management) and lasted on average 40 minutes. For the cooperatives and associations the same semistructured route was used. For FCC, a specific itinerary was chosen. In addition, the interviews were 
recorded, after the consent of the participants and later transcribed, which generated162 pages of material.

To validate the data obtained, the interviews were transcribed and sent to the subjects, as directed by Lincoln and Guba (1986), to confirm the contents resulting from the interview. Thus, all participants agreed with the content submitted and no changes were made to the transcripts. Moreover, it should be noted that the interview with the FCC was used to corroborate the results obtained. In other words, due to the FCC's unique activities (brand promotion, monitoring and promoting Denomination of Origin - DO) compared with cooperatives and associations, it was decided not to analyze it jointly.

To analyze the data obtained from the interviews and documents, we used the content analysis technique (Bardin, 2016), specifically frequency analysis, which consists of identifying the interviewees' responses and groupings according to the analytical categories of the study (Bardin, 2016). The categories analyzed were the four sources of competitive advantage from the relational perspective (Dyer \& Singh, 1998), and the forms of value appropriation from the relational view (Dyer et al., 2018). Therefore, the categorization started from the sources of creation and appropriation of value proposed by the literature.

\section{Results and discussions}

In order to identify the strategic actions of the actors who provide opportunities for value creation and appropriation, the four sources of competitive advantage from a relational perspective were considered as analytical categories (Dyer \& Singh, 1998), (i) specific assets; (ii) sharing knowledge and routine among organizations; (iii) complementary resources; and (iv) functioning of governance in the network. And the forms of value appropriation according to the Relational View (Dyer et al, 2018), (i) asymmetrical investment of assets; (ii) resource replication; (iii) development of additional resources; and (iv) preventing their resources from being imitated.

\section{Creating value}

\section{$\underline{\text { Leveraging specific assets }}$}

Asset specificity can be translated into doing something unique and specialized (Dyer \& Singh, 1998). In the case of CMR, it was found through interviews and document analysis that based on the "location", "certifications" and "professionalization", for some of the cooperatives and associations, value creation took place through cost reduction, product differentiation and market expansion. Table 4 summarizes the information. 
Table 4 - Creating value through specific assets

\begin{tabular}{|c|c|c|c|}
\hline \multicolumn{4}{|c|}{ Value creation in the CMR based on specific assets } \\
\hline Items observed & Entities & \multicolumn{2}{|c|}{ Forms of value creation } \\
\hline Being located in Cerrado Mineiro & \multirow{2}{*}{$\begin{array}{c}\mathrm{AA}, \mathrm{AB}, \mathrm{AC}, \mathrm{AD}, \mathrm{AE}, \mathrm{C} 1, \mathrm{C} 2 \\
\mathrm{C} 3, \mathrm{C} 4, \mathrm{C} 5\end{array}$} & \multirow{3}{*}{$\begin{array}{l}\text { Cost reduction; } \\
\text { differentiation; } \\
\text { expansion. }\end{array}$} & \multirow{3}{*}{$\begin{array}{r}\text { Product } \\
\text { Market }\end{array}$} \\
\hline Certifications and DO & & & \\
\hline Professionalization & $\begin{array}{c}\mathrm{AB} ; \mathrm{AC} ; \mathrm{AE}, \mathrm{C} 1, \mathrm{C} 2, \mathrm{C} 3, \mathrm{C} 4, \\
\mathrm{C} 5\end{array}$ & & \\
\hline
\end{tabular}

Source: Study results (2019).

Factors related to the location of the Cerrado Mineiro involve: (i) natural elements such as climate and soil which give cooperatives and associations a locational advantage over their competitors; (ii) possibility of new knowledge and new market opportunities; (iii) credibility of products that meet the region's classification criteria; and (iv) flexible communication between cooperative members. These factors corroborate the proposal of Dyer and Singh (1998) that the location decision involves the exchange of production routines which makes the process more agile and, consequently, reduces costs. The following statements exemplify the discussion:

We are part of a very privileged region. The location, the climate.... So, it is a very good visibility (Superintendent - Association A).

Communications are very direct and this makes it easier. Also some actions are punctual, so it viralizes very fast geographically we are very close (Superintendent - Association B).

Regarding certifications and DO, they reflect: (i) natural requirements (soil condition, altitude and others); (ii) human skills (best practice know-how) for coffee production and preparation; (iii) they are responsible for product differentiation; and (iv) assist in market expansion. Moreover, one of the small farmers' associations uses the Fairtrade seal and considers this certification a strategic factor adding value in coffee production. According to Zylbersztajn et al. (2016), the Cerrado was the first Brazilian coffee producing region to be awarded the DO, and such pioneering spirit made the region a model to be followed, and can also be considered a differentiating factor for the CMR (Moura, 2016), as shown by the statement of one of the interviewees:

But we have a tool that the others do not have, which is this information of origin denomination, our region it has a geographical indication, the others do not. The others only give you a guarantee that your product is sustainable. We do not, we give you quality. You can sell a coffee "Rainforest" UTZ" with 70, 75 points, you will sell a sealed coffee with over 80 points. You do the reading there, you will get the farm, the producer, the history of the farm, the history of the coffee, the plot, the score, the characteristics and so on (President Association D).

Also noteworthy is the professional management of CMR cooperatives and associations, giving them new possibilities to access different markets, given its ability to coordinate activities. For Dyer and Singh (1998), human specialization enables partners to work more effectively, reducing communication errors and improving the relationship between institutions. 


\section{$\underline{\text { Sharing knowledge and routines }}$}

Sharing knowledge and routines is considered an ongoing communication process between organizations enabling efforts to be directed at reducing costs and improving overall operational performance throughout the chain (Dyer \& Singh, 1998). It was noted that this category is the main form of value creation for cooperatives and associations in CMR, cited by the majority of the entities interviewed. Based on actions which lead to "sharing knowledge and routines", CMR creates value in coffee production expertise. The data are summarized in Table 5.

Table 5- Creating value through sharing knowledge and routines.

\begin{tabular}{l|c|c}
\hline \multicolumn{2}{c|}{ Value creation in the CMR based on sharing knowledge and routines } \\
\hline \multicolumn{1}{c|}{ Items observed } & Entities & Forms of value creation \\
\hline $\begin{array}{l}\text { Sharing routines for coffee production } \\
\text { and preparation }\end{array}$ & $\mathrm{AA} ; \mathrm{AB}, \mathrm{AC} ; \mathrm{AD} ; \mathrm{AE}, \mathrm{C} 1, \mathrm{C} 2$, & \\
$\begin{array}{l}\text { Holding internal events to facilitate } \\
\text { exchange of information }\end{array}$ & $\mathrm{AA}, \mathrm{AB} ; \mathrm{AC}, \mathrm{AE}, \mathrm{C} 1, \mathrm{C} 2, \mathrm{C} 3, \mathrm{C} 4$ & $\begin{array}{l}\text { Expertise in } \\
\text { production }\end{array}$ \\
\cline { 1 - 2 } Partnerships with SEBRAE & $\mathrm{AD} ; \mathrm{AC} ; \mathrm{AE}, \mathrm{C} 1, \mathrm{C} 2, \mathrm{C} 3, \mathrm{C} 4, \mathrm{C} 5$ & \\
\hline
\end{tabular}

Source: Study results (2019).

Among the ways of sharing coffee production and preparation routines, the following were found: (i) knowledge of strains; (ii) grain handling and drying methods; (iii) preparation and classification methods; (iv) beverage tasting; and (v) forms of sales. This sharing between cooperatives and associations is considered a factor in the region's expertise in coffee production, as the knowledge built is accessed and recombined (Grant, 1991) in a unique way by each institution (Nagai et al., 2016; Moura, 2016; Azevedo, 2018), generating know-how for coffee production (Moura, 2016). As illustrated by the statement of the superintendent of one of the associations:

We work a lot with the social network, contact, meetings that we have, interpersonal contact that we do in several events, there are lots of events here, then we meet and pass on these knowledges (Superintendent Association B).

Regarding the holding of events, we highlight: (i) management activity; (ii) training in the area; and (iii) field days. It is noteworthy that the holding of specific events is a key strategic action enabling the exchange of knowledge, as well as contributing to strengthening ties between entities, partnerships and providing innovation (Nagai et al., 2016). Moreover, it should be noted that for two associations (AA and $\mathrm{AE}$ ), holding events is a way of generating revenue.

Partnerships developed with SEBRAE (Brazilian Micro and Small Business Support Service) also boost production expertise. The importance of these partnerships is unanimous for both cooperatives and associations as the following statements illustrate. 
Look, SEBRAE is our great partner, a great partner indeed (President - Association E).

The quality Cluster process has generated good results, and this is the result of partnerships mainly as SEBRAE (Financial Administrative Manager - Cooperative 3).

They recognize SEBRAE's role in building new knowledge. One of the outstanding projects is Educampo. This project is the result of a partnership formed in 2002 between the CMR and SEBRAE to implement farm management routines. To this end, consultants were allocated to assist producers in managing their properties, assisting with information related to total activity cost, process management and technological management of the farms (Moura, 2016).

\section{Resource complementing}

The resource complementation category consists of resources and capabilities derived from relationships (Dyer \& Singh, 1998). The authors point out that such resources and capabilities cannot be obtained in the market, which ensures synergy and allows the actors involved to benefit from these relationships. At the CMR, it was found that based on "traceability" and "being part of CMR", entities create value in disseminating and differentiating brands. The data are synthesized in Table 6.

Table 6 - Creating value through complementary resources

\begin{tabular}{l|l|l}
\hline \multicolumn{2}{c}{ Value creation in the CMR based on complementary resources and capacities } \\
\hline \multicolumn{1}{c|}{ Items observed } & \multicolumn{1}{c}{ Entities } & \multicolumn{1}{c}{ Forms of value creation } \\
\hline Traceability & $\mathrm{AA} ; \mathrm{AB} ; \mathrm{AD}, \mathrm{AE}, \mathrm{C} 2, \mathrm{C} 5$ & $\begin{array}{l}\text { Brand } \\
\text { Differentiation }\end{array}$ \\
\hline Being part of the CMR & $\mathrm{AA}, \mathrm{AB}, \mathrm{AC}, \mathrm{AD}, \mathrm{AE}, \mathrm{C} 1, \mathrm{C} 2, \mathrm{C} 3, \mathrm{C} 4$ & \multicolumn{1}{c}{ dination; } \\
\hline
\end{tabular}

Source: Study results (2019)

Factors related to traceability are: (i) producer history; (ii) production details; and (iii) beverage characteristics. In this sense, traceability, besides being a factor driving CMR's brand, allows entities to differentiate themselves in the market. In the perception of the DO coordinator, in order for the CMR brand to bring effective results to the entities and consolidate itself in the market, actions assuring product quality, professionalization and organization of the entities around a common goal become essential, corroborating Moura's proposal (2016). These conclusions can be illustrated by the following passages: 
So, you have to have products with quality and constancy to offer to the market out there, so for that, you have to bring knowledge... work sustainability... work with the action plan lines. For the project of demand generation, for the coffee with controlled origin, to be consolidated ... advertising is pointless if you don't have quality and constancy here at the base to offer and the sustainability of these people (Coordinator of DO FCC).

You would agree that if you have an organization behind you, a federation aligned and carrying our brand, working this way we will value our product, I see this as another consumer demand (...) It's a project that the federation has been developing, of "QR - code", if your coffee is certified by the federation, it has a minimum score, above 80 , it has to have a certain level of sustainability, use products with registration, employees all registered, respect the environmental part and then this seal goes on the packaging of the coffee. And then the guy gets his cell phone in Japan, or wherever else it goes, he reads the "QR - code" there, and he will know who the producer is, how many points the coffee got, the characteristics of the coffee, that it is sustainable, that it meets all the standards of sustainability, certification or the federation of the Cerrado Mineiro or other certification as well. (President - Association D).

Moreover, being part of CMR means meeting a coffee quality standard which converges to promotion of its brand in the external environment, evidencing product differentiation, which is perceived as an advantage over competitors.

Complementarily, Pereira and Pedrozo (2005) mention that the notion of complementarity can be broadened by also involving compatibility requirements between organizations, which can generate better use of synergies and access to shared resources. The study highlights complementarity in activities focused on research and development, sustainability issues and accessibility to experimental fields.

\section{$\underline{\text { Governance mechanisms }}$}

Governance is a source of competitive advantage based on the search for a structure and mechanisms able to minimize transaction costs (Dyer \& Singh, 1998). In the case of the CMR, it was found that the FCC is cited as the governance entity, being the articulator of the strategy of the entire region, according to the interviewees. Moreover, based on the "protection and promotion of the DO", "regular meetings" and the "institutional structure", value is created by strengthening the brand and expanding the market. The data are summarized in Table 7.

Table 7 - Creating value through governance mechanisms

\begin{tabular}{|c|c|c|c|}
\hline \multicolumn{4}{|c|}{ Value creation in the CMR based on governance mechanisms } \\
\hline Items observed & Entities & Value creation re & \\
\hline $\mathrm{DO}$ & \multirow{3}{*}{$\begin{array}{c}\mathrm{AA}, \mathrm{AB}, \mathrm{AC}, \mathrm{AD}, \mathrm{AE}, \mathrm{C} 1 \\
\mathrm{C} 2, \mathrm{C} 3, \mathrm{C} 4, \mathrm{C} 5\end{array}$} & \multirow{3}{*}{$\begin{array}{l}\text { Brand strengthening; } \\
\text { expansion }\end{array}$} & \multirow{3}{*}{ Market } \\
\hline $\begin{array}{l}\text { Regular meetings to discuss joint } \\
\text { actions }\end{array}$ & & & \\
\hline Institutional structure of the system & & & \\
\hline
\end{tabular}

Source: Study results (2019).

The FCC takes the following precautions regarding DO: (i) protection, representation and promotion; (ii) establishing rules of use; (iii) producers must be affiliated with at least one CMR 
cooperative or association in order to gain access to the seal. These are some of the factors which help to strengthen the brand. Furthermore, in the FCC Development Plan, it reaffirms its commitment to promoting the Cerrado Mineiro brand and the DO.

Regarding the regular meetings, projects are developed in partnership with SEBRAE; regular meetings to align FCC actions; promote integration events and promote the feeling of belonging to the group. Such FCC activities support Dyer and Singh's (1998) proposal that governance mechanisms are capable of resulting in other ways of creating value, such as investing in specific assets and sharing complementary knowledge and resources.

Finally, the FCC's institutional structure is recognized by most cooperatives and associations, there is recognition of the FCC's role. For entities, the FCC is essential to achieving future results and organizing the network. In addition, in the perception of one of the interviewees, the way the FCC is organized favors network coordination actions, as shown by the statement of one of the interviewees:

So, this is the relationship between the cooperatives, it turns out that they are in fact united, without necessarily being united by law. That is, there is not a central of cooperatives, which makes all of them enter into a process of horizontality, without any hierarchical verticalization, without any functional verticalization, but a horizontality, more for a circogram, than for an organogram. And that is what gives fluency to this process. So, these are the affinities, these are the ways of working in this context. You will notice that they have many similarities, hmm.... even statute proximities, but each one with its autonomy (Superintendent - Cooperative $1)$.

It is important to emphasize the strong use of mechanisms of relational governance by the FCC. Relational governance can be understood as a complex instrument, which potentializes the development of complementary assets and resources among companies. Therefore, relational governance has a significant impact on the competitiveness of the network, given its impact in combating opportunistic behavior and cheating (Claro et al., 2003).

\section{Appropriating value}

\section{Asymmetric investment of assets}

Dyer et al. (2018) stated that when asymmetric investment in specific assets occurs between partners, the company that has made the least investment in assets over time is likely to have greater bargaining power in future negotiations, given the nature of the assets. In this research, it was assumed that this bargaining power also stems from asymmetrical relationships, however, the stronger party (the organization that has invested more resources than others) may be able to appropriate more value from the relationship, as it controls most of the resources used in the collaboration, and consequently, has greater bargaining power (Pemartín \& Rodrígues-Escudero, 2017). Likewise, it was observed at CMR that, given the opportunities of "Being located in the Cerrado Mineiro" "Certifications and DO" and "Professionalization", some entities have been capturing value, mainly due to the possibility of selling quality coffee, as shown in Table 8. 
Table 8 - Value appropriation through asymmetric investment in assets

\begin{tabular}{c|c|c|}
\hline \multicolumn{2}{|c|}{$\begin{array}{c}\text { Value appropriation in the CMR based on asymmetric investment in specific assets } \\
\begin{array}{c}\text { Circumstances leading to value } \\
\text { creation }\end{array}\end{array}$} & Entities \\
\hline $\begin{array}{c}\text { Being located in the Cerrado } \\
\text { Mineiro }\end{array}$ & $\begin{array}{c}\mathrm{C} 1, \mathrm{C} 2, \mathrm{C} 3, \mathrm{C} 4, \mathrm{C} 5, \mathrm{AD}, \mathrm{AE}, \\
\text { Producers not affiliated with the } \\
\mathrm{FCC} .\end{array}$ & $\begin{array}{l}\text { Sale of polue appropriation } \\
\text { coffee }\end{array}$ \\
\hline Certifications and DO & $\mathrm{C} 1, \mathrm{C} 2, \mathrm{C} 3, \mathrm{C} 4, \mathrm{C} 5, \mathrm{AD}, \mathrm{AE}$ & \\
\hline Professionalization & & \\
\hline
\end{tabular}

Source: Study results (2019).

Cooperatives are the main entities which capture value in the face of opportunities created. The main justification lies in understanding the statutory nature of cooperatives themselves, especially the emphasis on sales. It was noted in the interviews that the sales of sealed coffee remains timely in most cooperatives, although there are projects to expand the use of the seal to the entire network. In this way, the opportunities offered by the certifications and the DO can be seized, mainly by those entities which can sell or which do sell coffee using the CMR seal, as shown in the statement of the Superintendent of Cooperative 1. Complementarily, Nunes et al. (2013), when investigating the specialty coffee market in Brazil, find that certifications have a particular function of increasing the added value of the product.

The cooperatives already work with the idea of only being able to sell coffee with the seal (as long as it reaches the established minimum quality). So, that's already a certain advantage. The cooperative seals many coffees. It makes a point of selling these sealed coffees. And for some segments, they already understand that this is a difference. They already know that they buy, it will be from where they buy and that unfortunately, in the foreign market, there is a lot of confusion about Brazil as a whole, but there are people out there who think the cerrado mineiro is located in the state of Paraná (Superintendent - Cooperative 1).

Fischer and Sojer (2015) place significant weight on the process of value appropriation. For the authors, in certain contexts, some organizations are able to appropriate more value than they create. In the case of CMR, it was noted that some non-network actors take advantage of the opportunity and manage to sell their coffee, even if not affiliated with the FCC. This view is also perceived by cooperatives and associations as a factor for concern, especially for the appropriation of results. According to the interviewees, there are many producers who are not affiliated with the FCC mainly due to the necessary adjustments regarding certification standards, however, being located in the Cerrado Mineiro, they are able to sell the coffee at a price above the market. The speech of the president of one of the associations of the network illustrates this matter.

I see that there are many producers outside the system still, that could be inside, 'but the guy will come here inside my farm to inspect, that I have to do this, that I have to do that', and being apathetic, there is a lot of apatheticness, 'Oh no, I would have to make a structure for the pesticide', 'no, I won't mess with this', there is a lot of this, these producers don't care" and sometimes they sell their coffee as differentiated because they are located at the CMR (President - Association D). 


\section{$\underline{\text { Replication of partner resources }}$}

According to Dyer et al. (2018), the bargaining power between organizations can also be modified when a particular organization is able to replicate or replace its partner's knowledge and resources. According to the authors, in a dynamic context, when this happens, the organization with such absorptive capacity may be more likely to appropriate the created value. Thus, at CMR, it was found that given the opportunities for value creation already mapped: "Sharing routines for coffee production and preparation", "Holding internal events" and "Partnerships with Sebrae", some cooperatives and associations capture part of the value generated through the learning process, as shown in Table 9.

Table 9 - Value appropriation based on resource replication

Value appropriation in the CMR based on replication of partner resources

\begin{tabular}{l|c|c}
\hline \multicolumn{1}{c|}{ Circumstances leading to value creation } & Entities & $\begin{array}{c}\text { Forms of value } \\
\text { appropriation }\end{array}$ \\
\hline $\begin{array}{l}\text { Sharing routines for coffee production and } \\
\text { preparation }\end{array}$ & AA, AB, AC, AD, AE, C1, & Learning \\
\hline $\begin{array}{l}\text { Holding internal events to facilitate } \\
\text { information exchange }\end{array}$ & C2, 4 \\
\hline Partnerships with SEBRAE & & \\
\hline Source: Study results (2019). &
\end{tabular}

Among the ways of exemplifying learning, the following stand out: (i) collective discussions; (ii) information sharing on coffee production and preparation processes; (iii) close contact with SEBRAE; (iv) knowledge transfer between network organizations; and (v) proximity to universities. These factors corroborate the proposal of Sacomano et al. (2015) that the issue of learning is essential at all levels of analysis of cooperation networks. The following statement illustrates the fact:

We absorb from them the ability to relate with the producer, ability to develop projects, this more professional part of them we get, more administratively than technically (Superintendent - Association B).

However, it was found that C5 does not recognize gains derived from knowledge sharing, nor does it recognize that it captures this value. For the interviewee, the shared information is timely and does not offer the cooperative a competitive advantage. Thus, as highlighted by Dyer and Singh (1998), although an organization has access to new knowledge, it does not guarantee superior performance, which ensures its advantage is the ability to absorb and internalize knowledge.

Developing additional resources

Dyer et al. (2018) state that a networked organization can construct or acquire new resources that are valuable to the relationship. When this happens, this organization can capture more value over time, given its potential to trade the synergistic resources it develops. In the case of CMR, given the 
opportunities for value creation "Being part of the CMR" and "Traceability", some cooperatives and associations have captured value through the premium paid for the cooperative's coffee and the appreciation of the producer (Table 10).

Table 10 - Value appropriation based on developing additional resources

\begin{tabular}{|l|c|c|}
\hline \multicolumn{2}{|c|}{ Value appropriation in the CMR based on developing additional resources } \\
\hline $\begin{array}{c}\text { Circumstances leading to value } \\
\text { creation }\end{array}$ & Entities & Forms of value appropriation \\
\hline Being part of the CMR & AA, AE, C1, C2, C4 & Quality awards and producer appreciation \\
\hline Traceability &
\end{tabular}

Source: Study results (2019).

The possibilities of awards offered by the network are: "Cerrado Mineiro Region Award" and "Cafés authorias", both offered by the FCC. According to the superintendent of C1, the "Cafés authorias" award is seen as a quality award and goes beyond the financial dimension, as it allows cooperatives and associations to bring to the producer a sense of belonging to the CMR.

Because when we talk about region, that' s the way to bring attention to the production (...) all we do is to value the work of the people, the producer, the production. As we do, for example, the producer's edition, here in the coffee shop: an edition in which the producer does not sell a huge amount. There are two bags of coffee, but he sells that coffee with his name, with his history, with the differentiated quality. He won't do all the production that way, but this moment for him, is not an economic one, it's a moment of self-realization. It's not an egocentric moment, it's a moment of self-realization, where the producer goes like this: "I reached my goal, my goal to produce quality". That's why they participate in contests, it's not for vanity, it's for self-satisfaction, for self-realization. To say: "Look, what was nobody's land, inhospitable land, look at what it does... the product it makes". (Superintendent - Cooperative 1).

The CMR Journal (2017) has testimonials from producers who have won the quality award. The producers report the importance of the award and highlight the possibility of connection with other producers to exchange experiences and expand the market. Complementarily, in 2017, this award involved $\mathrm{R} \$ 873,696.80$ with the sale of lots (CMR, 2017), reaffirming its importance for the entire chain.

For Moura (2016), the premium paid for the cooperative/associate's coffee acts as a form of producer loyalty, as there is an appreciation of the producer and the production. In the FCC's view, enhancing producer and production is the most effective way for cooperatives and associations to capture value. For the DO Coordinator, the appropriation of value also depends on entities which must seek closer ties with the producer, developing internal projects and expanding the sense of belonging. Thus, the entities $\mathrm{AA}, \mathrm{AE}, \mathrm{C} 1, \mathrm{C} 2$ and $\mathrm{C} 4$ manage to capture part of the value generated by establishing new forms of relationship as the producer, mainly through internal quality competitions, such as the case of $\mathrm{AA}$ and $\mathrm{AE}$, and appreciation of the producer. 


\section{Preventing imitation of the resources}

For Dyer et al. (2018), a partner's resources may become less valuable and rare due to imitation by competitors. When this happens, the company's bargaining power is reduced, as resources cannot be considered rare. Likewise, an organization can appropriate more value when it can create mechanisms which prevent the imitation of its resources. At CMR, based on the opportunities that lead to value creation, provided by "DO and Brand", "Regular Meetings" and "System Institutional Structure", it was found that cooperatives capture value through enhancing complementary assets and resources, which offer a unique way for coffee production and preparation, as shown in Table 11.

Table 11 - Value appropriation based on blocking and imitating resources

Value appropriation in the CMR based on creating barriers to prevent imitation of resources

\begin{tabular}{l|c|c}
\hline \multicolumn{1}{c|}{$\begin{array}{c}\text { Circumstances leading to value } \\
\text { creation }\end{array}$} & Entities & Forms of value appropriation \\
\cline { 1 - 1 } DO and brand & \multirow{2}{*}{$\begin{array}{c}\mathrm{AA}, \mathrm{AB}, \mathrm{AC}, \mathrm{AD}, \mathrm{AE}, \\
\mathrm{C} 1, \mathrm{C} 2, \mathrm{C} 3, \mathrm{C} 4, \mathrm{C} 5\end{array}$} & $\begin{array}{l}\text { Strengthening complementary assets } \\
\text { and resources }\end{array}$ \\
\cline { 1 - 2 } $\begin{array}{l}\text { actions meetings to discuss joint } \\
\text { Institutional structure of the system }\end{array}$ &
\end{tabular}

Source: Study results (2019).

There are some actions at the FCC aimed at preventing the imitation of resources. These actions include: (i) the structure of the network through establishing executive committees which reinforce trust among the actors; (ii) fostering the spirit of belonging, as all cooperatives and associations have decision-making power; and (iii) the regular meetings and promotion of the DO guarantee more security to the members and strengthen ties between them. The DO coordinator's statement illustrates the importance of network structuring.

The Federation has a role of political-institutional representation of these cooperatives and associations. The maintainers are the cooperatives... because the movement is bigger than the associations movement, right? There's no way... So they are the maintainers, through the movement rate. The one that circulates more coffee, contributes with more, the one that circulates less, contributes less, to be fair, right? While as they are the maintainers, they compose the executive committee of the Federation of Coffee Growers. So they also make decisions about the system. The associations occupy seats in the assembly. So, they participate in decisions regarding changes in the bylaws and regarding things that enter the assembly (DO - FCC Coordinator).

The network structure and meetings are pointed out by Balestrin et al. (2014) and Carvalho et al. (2018), respectively, as important actions for developing trust in the network, as well as promoting advantages that are difficult to imitate by companies outside the network.

\section{Conclusions}

The aim of this paper was to analyze how the processes of value creation and appropriation manifests itself in a horizontal agribusiness network. Regarding the value creation process, besides 
confirming the four sources of value creation proposed by Dyer and Singh (1998), the study advances by mapping the value created from the categories presented by the mentioned authors. In the "Leveraging specific assets" category, the values created are related to cost reduction, product differentiation and market expansion. The "Sharing knowledge and routines" category was the main form of value creation for cooperatives and associations, creating value for expertise in coffee production. The "Resource complementing" category created value through brand differentiation and dissemination. The "Governance Mechanisms" category created value by strengthening the brand and expanding the market.

Based on the results for value creation, efforts were directed toward the process of value appropriation. It is worth noting that to analyze this objective, some changes in the analytical categories were necessary, since the original categories were conceived from the perspective of vertical relationships. Therefore, this study makes advances, in an exploratory attempt, by adjusting the categories for horizontal relationships.

The values are appropriated in the category "Asymmetric investment in specific assets" for the sale of potential quality coffee. In the "Partner resource replication" category, values are captured through the learning process. The category "Development of additional resources" shows values appropriated through the premium paid on the cooperative/association's coffee and appreciation of the producer. In the category "Preventing imitation of resources", it was found that cooperatives and associations capture value through enhancing complementary assets and resources, which offer a unique way of preparing and producing coffee.

Overall, associations were found to create value primarily by sharing routines and knowledge and through external partnerships. Learning can be seen as the value captured from these relationships. Also mapped was the fact that the entities which most appropriated the value generated are those which control the most valuable resources, as suggested by Dyer et al. (2018).

In the value creation process, it was noted that in some sources of competitive advantage, such as the sharing of routines, information and processes, the entities were required to develop specific relationship and management skills. However, some value creation opportunities go beyond organizations' internal skills, such as "Being located in the Cerrado Mineiro", "Traceability", "Certifications and Denomination of Origin", "Partnerships with SEBRAE", and "Institutional structure of the system". Thus, for these opportunities for value creation, organizations' internal capabilities would not be decisive.

With regards the value appropriation process, the same weightings apply. Given the forms of value appropriation "Learning" and "Strengthening complementary resources", the development of specific relationship and management skills is essential, considering the aspects of knowledge and human interaction encompassed. However, some forms of value appropriation do not require internal skills development as they are achieved by being located in the Cerrado Mineiro or being part of the network. 
Such considerations reinforce the fine line between the processes of value creation and appropriation. In other words, in addition to developing internal skills and abilities essential for both value creation and appropriation, organizations must devise strategies to strike a balance between these processes. Furthermore, evaluating partnerships is also critical to leveraging overall gains.

It should be noted that the study does not exhaust the sources of value creation and appropriation in the Cerrado Mineiro Region. In other words, new forms of value creation/appropriation can be pointed out in this case, however, they would be better explored by other theoretical contributions, and not by the Dyer and Singh (1998) and Dyer et al. (2018) Relational View approach used in this study.

Among the main contributions of this study, we highlight the association of value creation and appropriation with the case study, and the fact that the study contributes to an analysis of horizontal rather than only vertical networks, as proposed by Dyer et al. (2018).

The main limitation of the research is the lack of participation of all entities making up the network. Moreover, secondary data was also a limitation. Some entities did not have or did not provide additional information on their routines.

As proposals for future studies, we highlight investigating the processes of creation and appropriation of value from the perspective of producers and also of customers/consumers in order to understand the value chain in this segment. Likewise, it is also possible to investigate whether there is value creation/appropriation for the internal environment (coffee farmers, organizations involved, among others).

\section{References}

Azevedo A.S. (2018). As Cafeiculturas do Cerrado Mineiro e do Sul de Minas no Escopo das Singularidades Institucionais. Dissertação de Mestrado em Administração, Universidade Federal de Lavras, Lavras-MG, Brasil.

Balestrin, A., \& Verschoore, J. (2016). Redes de Cooperação Empresarial-: Estratégias de Gestão na Nova Economia. Bookman editora.

Balestrin A., Verschoore J.R., Perucia A. (2014). A visão relacional da estratégia: evidências empíricas em redes de cooperação empresarial. Revista Base (Administração e Contabilidade) da UNISINOS, 11(1): 47-58.

Bardin L. (2016). Análise de Conteúdo. Tradução Luís Antero Reto, Augusto Pinheiro. Edições 70: São Paulo.

Barney J.B. (1991). Firm resources and sustained competitive advantage. Journal of Management, 17(1): $99-120$.

Barney J.B., Hesterly W. (2006). Organizational economics: Understanding the relationship between organizations and economic analysis. The SAGE handbook of organization studies: London, 110-148. 
Bowman C., Ambrosini V. (2000). Value creation versus value capture: towards a coherent definition of value in strategy. British Journal of Management, 11(1):1-15.

Carvalho J.F., Wegner D., Begnis H.S.M., Antunes Júnior J. (2018). A Cooperação Entre Redes de Pequenas Empresas: Antecedentes, Etapas e Resultados da Estratégia de Intercooperação. Revista de Empreendedorismo e Gestão de Pequenas Empresas (REGEPE), 7(1): 35-70.

Claro, D. P., Hagelaar, G., \& Omta, O. (2003). The determinants of relational governance and performance: how to manage business relationships?. Industrial Marketing Management, 32(8), 703-716.

Conab - Companhia Nacional de Abastecimento. (2020) Histórico Mensal Café. Available at: https://www.conab.gov.br/info-agro/analises-do-mercado-agropecuario-e-extrativista/analises-domercado/historico-mensal-de-cafe (Acessed 19 Jan 2021).

Coff R.W. (2010). The coevolution of rent appropriation and capability development. Strategic Management Journal, 31(7): 711-733.

Coff R.W. (1999). When competitive advantage doesn't lead to performance: the resource-based view and stakeholder bargaining power. Organization Science, 10(2): 119-133.

Corte V.D., Gaudio G.D. (2014). A literature review on value creation and value capturing. Strategic Management Studies, 11(2): 328-346.

Dubosson-Torbay M., Osterwalder A., Pigneur Y. (2002). E-business model design, classification, and measurements. Thunderbird International Business Review, 44(1): 5-23.

Dyer J.H., Singh H. (1998). The relational view: Cooperative strategy and sources of interorganizational competitive advantage. Academy of Management Review, 23(4): 660-679.

Dyer J.H., Singh H., Hesterly W.S. (2018). The relational view revisited: A dynamic perspective on value creation and value capture. Strategic Management Journal. SI: 1-44.

Fischer T., Sojer M. (2015). On the relationship of value creation and value capture: An empirical analysis. Journal of General Management, 41(2): 79-106.

Gandia R., Parmentier G. (2017). Optimizing value creation and value capture with a digital multisided business model. Strategic Change, 26(4): 323-331.

Grant R.M. (1991). The resource-based theory of competitive advantage: implications for strategy formulation. California Management Review, 33(3): 114-135.

Gulati R. (1999). Network location and learning: the influence of network resources and firm capabilities on alliance formation. Strategic Management Journal, 20(5): 397-420.

Ito N.C., Hayashi Junior P., Gimenez F.A.P., Fensterseifer J.E. (2012). Valor e vantagem competitiva: buscando definições, relações e repercussões. Revista de Administração Contemporânea, 16(2): 290-307.

Lavie D. (2006). The competitive advantage of interconnected firms: An extension of the resourcebased view. Academy of Management Review, 31: 638-658.

Lee H., Kim M.S., Kim K.K. (2014). Interorganizational information systems visibility and supply chain performance. International Journal of Information Management, 34(2): 285-295. 
Lepak D.P., Smith K.G., Taylor M.S. (2007). Value creation and value capture: A multilevel perspective. Academy of Management Review, 32(1): 180-194.

Lincoln Y.S., Guba E.G. (1986). But is it rigorous? Trustworthiness and authenticity in naturalistic evaluation. New directions for evaluation, 30: 73-84.

Makadok R., Coff R. (2002). The Theory of Value and the Value of Theory: Breaking New Ground Versus Reinventing the Wheel. The Academy of Management Review, 27(1): 10-13.

Martins G.S., Rossoni L., Duarte A.L.C.M., Martins R.S. (2017). Supply chain relationships: exploring the effects of both relational and structural embeddedness on operational performance. International Journal of Procurement Management, 10(5): 639-664.

Marx K. (1990). Capital: a critique of political economy. Penguin Books: London.

Miguel P.L.S., Brito L.A.L., Fernandes A.R., Tescari F.V.C.S. (2014). Relational value creation and appropriate on in buyer-supplier relationships. International Journal of Physical Distribution and Logistics Management, 44(7): 559-576.

Mizik N., Jacobson R. (2003). Trading off between value creation and value appropriation: The financial implications of shifts in strategic emphasis. Journal of Marketing, 67(1): 63-76.

Moura E.F. (2016). As Estratégias de Internacionalização das Cooperativas Agropecuárias de Café da Região do Cerrado Mineiro. Dissertação de Mestrado em Administração, Universidade Federal de Uberlândia, Uberlândia-MG, Brasil.

Nagai, D. K., Pigatto, G. A. S., \& Lourenzani, A. E. B. S. (2016). Formas de inovação na agricultura: O caso da denominação de origem protegida na produção de café de Cerrado Mineiro. Revista ESPACIOS| Vol. 37 (Nº9).

Nagai D.K., Pigatto G.A.S., Queiroz, T.R. (2016). Fontes e redes de informação na produção cafeeira do Cerrado Mineiro-MG. Interações (Campo Grande), 17(4): 655-670.

Ngugi I.K., Johnsen R.E., Erdélyi, P. (2010). Relational capabilities for value co-creation and innovation in SMEs. Journal of small business and enterprise development, 17(2): 260-278.

Nunes R., Silva V.L.S., Saes M.S.M., Sousa R.N.R.L., Souza, R.C. (2013). Incentives to differentiation strategies for Brazilian coffee producers. Revista de Economia e Administração, 12(2): 165-179.

Pavlínek P., Ženka J. (2016). Value creation and value capture in the automotive industry: Empirical evidence from Czechia. Environment and Planning A, 48(5): 937-959.

Pemartín M.; Rodríguez-Escudero A.I. (2017). NPD collaboration in an asymmetrical investment context: A relational view. Journal of Engineering and Technology Management, 45: 1-17.

Pereira B.A.D., Pedrozo E.A. (2005). Contribuições à consolidação da teoria estratégica interorganizacional: uma análise dos relacionamentos horizontais. Revista de Administração Contemporânea, 9(4): 141-161.

Peteraf M.A., Barney J.B. (2003). Unraveling the resource-based tangle. Managerial and decision economics, 24(4): 309-323.

Pitelis C. (2009). The co-evolution of organizational value capture, value creation and sustainable advantage. Organization Studies, 30(10): 1115-1139. 
Porter M.E. (1985). Competitive advantage. Free Press: New York.

CMR - Região do Cerrado Mineiro. (2017). Jornal do Cerrado Mineiro. Impresso.

Reypens C., Lievens A., Blazevic V. (2016). Leveraging value in multi-stakeholder innovation networks: A process framework for value co-creation and capture. Industrial Marketing Management, 56: 40-50.

Sacomano Neto, M., Corrêa, D.A., Truzzi, O. M. S. (2015). Transferência de conhecimento em redes de empresas: um estudo em uma planta modular da indústria automotiva. Revista Economia \& Gestão, 15(41): 33-56.

Wang Y., Rajagopalan N. (2015). Alliance capabilities: review and research agenda. Journal of Management, 41(1): 236-260.

Yin R.K. (2001). Estudo de Caso: Planejamento e Métodos. Bookman: Porto Alegre.

Zhang L., Wang, J. (2018). Research on the relationship between relational capital and relational rent. Cogent Economics \& Finance, 6 (1431091): 1-18.

Zhao, S., Yu, H., Xu, Y., \& Bi, Z. (2014). Relationship-specific investment, value creation, and value appropriation in cooperative innovation. Information Technology and Management, 15(2), 119-130.

Zylbersztajn D., Giordano S.R., Vita C.L.R. (2016). Estudo de caso - Denominação de Origem (DO) do Cerrado. In: Relatório Técnico: Estudos de caso sobre inovação na cafeicultura brasileira, 84 105. 